\title{
Öğretmenlerin Pozitif Psikolojik Sermaye ve Örgütsel Özdeşleşmeleri Arasındaki İlişki ${ }^{1}$
}

\section{The Relationship Between Positive Psychological Capital and Organizational Identification}

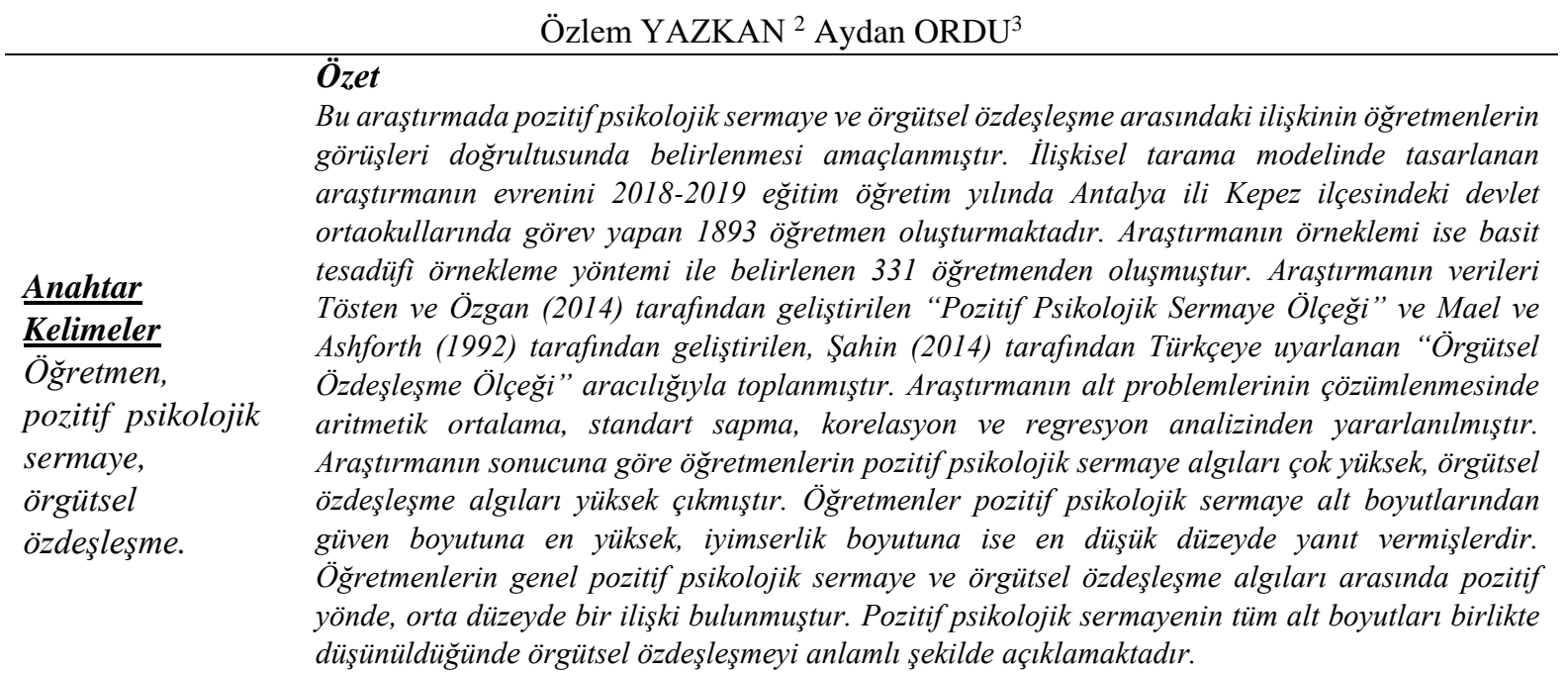

\section{Abstract}

In this study, it is aimed to investigate the relationship between positive psychological capital and organizational identification according to teachers' views. The population of the study using the

$\underline{\text { Key Word }}$ relational survey model is 1893 teachers working in public secondary schools in the Kepez district

Teacher, of Antalya province in the academic year of 2018-2019. The sample of the research consists of 331 positive teachers determined by random sampling. The data of the study were collected through "Positive psychological capital, Psychological Capital Scale" developed by Tösten and Özgan (2014) and "Organizational Identification Scale" developed by Mael and Ashforth (1992) and adapted to Turkish by Şahin (2014). The arithmetic mean, standard deviation, correlation and regression analysis were used to organizational identification. analyse sub-problems of the research. According to the results of the study, the positive psychological capital perceptions of teachers were very high and the perceptions of organizational identification were high. Teachers responded to the confidence at the highest level and the optimism dimension at the lowest level for the positive psychological capital sub-dimensions. A moderate relationship was found between the general positive psychological capital and organizational identification perceptions of teachers in a positive direction. Considering all sub-dimensions of positive psychological capital together, explains organizational identification significantly.

\begin{tabular}{|c|c|}
\hline $\begin{array}{l}\text { Atıf için: } \\
\text { For Citation }\end{array}$ & $\begin{array}{l}\text { Yazkan, Ö., \& Ordu, A. (2021). Öğretmenlerin pozitif psikolojik sermaye ve örgütsel } \\
\text { özdeşleşmeleri arasındaki ilişki. Muğla Sitkı Koçman Üniversitesi Eğitim Fakültesi } \\
\text { [MSKU Journal of Education], 8(1), 274-288. DOI: } 10.21666 / \text { muefd.832221 }\end{array}$ \\
\hline & Received: 27.11.2020 $\quad$ Accepted: 04.03.2021 $\quad$ Published: 01.05.2021 \\
\hline
\end{tabular}

İnsanlar aracılığıyla oluşturulmuş ve insanların gereksinimlerini giderebilmek amacı ile kurulmuş yani varoluş sebebi insan olan örgütler, diğer örgütlerle aralarındaki yarışma gücünü artırabilmek için çalışanlarını daha çok önemsemeye başlamışlardır (Keleş, 2011). Çünkü örgütlerin sahip oldukları en

\footnotetext{
${ }^{1}$ Bu çalışma birinci yazarın "Pozitif psikolojik sermaye ile örgütsel özdeşleşme arasındaki ilişki” başlıkl yüksek lisans tezinin bir bölümünden derlenmiştir.

${ }^{2}$ Antalya Milli Eğitim Müdürlüğü, ozlemyazkan@gmail.com, ORCID: 0000-0002-5071-6352

${ }^{3}$ Pamukkale Üniversitesi, Eğitim Bilimleri Bölümü, akursunoglu@gmail.com, ORCID: 0000-0002-2068-7992
} 
değerli unsurlarından birisi, insan kaynağıdır ve insan kaynağı, örgütlerin amaçlarına ulaşabilmesi konusunda önemli bir role sahiptir (Öğ̈̈t, Akgemci ve Demirsel, 2004, s.278-279).

Son yıllarda pozitif psikolojiye olan ilginin artmasıyla çalışanların işiyle ve buna bağlı olarak örgütleriyle bütünleşmesi araştırmacılar tarafından sıklıkla ele alınmaktadır (Ötken ve Erben, 2010, s. 94). Gerek yurt dışında gerek yurt içinde yapılan araştırmalar sonucunda, çalışanların kendilerini işlerine bağlı hissetmelerinin; iş devamsızlığının azalması, iş bırakmaların azalması, iş stresinin azalması ve iş başarısı, iş memnuniyeti gibi pek çok pozitif örgütsel davranışın öncülü olabildiği görülmektedir (Erdem, Gökmen, Türen, 2015, s. 40). Bu noktada ise örgütsel özdeşleşme kavramı dikkat çekmektedir. Örgüt içerisinde çalışmakta olan bireylerin, iş yerlerinde huzurlu olmaları, yaptıkları işten mutlu olmaları ve kurumlarına olumlu duygular beslemeleri kurumları ile bir bütün haline gelmelerini gerçekleştirebilir. Böylelikle çalışanlar kendilerini, işlerinin ve de işteki ortamlarının bir parçası olarak hissedebilirler (Akman, 2017, s.72). Çalışanların kendilerini örgütlerinin bir parçası şeklinde algılamaları ve örgütleriyle psikolojik bir bağ kurmaları olarak açıklanan örgütsel özdeşleşme örgütlerin istediği bir durumdur (Turunç ve Çelik, 2010, s.184).

$\mathrm{Bu}$ araştırmada öğretmenlerin pozitif psikolojik sermayeleri ve örgütsel özdeşleşmeleri arasındaki ilişkinin araştırılması amaçlanmıştır. Pozitif psikolojik sermayenin örgütsel özdeşleşmeye önemli bir etkisinin olduğu düşünülmektedir. Buradan elde edilen veriler doğrultusunda öğretmenlerin kurum içerisindeki psikolojik sermayelerinin iyi bir şekilde yönetilmesiyle; örgütsel özdeşleşme seviyelerinin de iyi olacağı, öğretmenlerin belirlenen hedeflere ulaşma konusunda örgütüne yardımcı olacağı düşünülmektedir.

\section{Pozitif Psikolojik Sermaye}

Psikoloji, ilk zamanlarında bireylerin güçlü yanlarından çok bireysel problemlerle uğraşmıştır. $\mathrm{Bu}$ zamana kadar üzerinde incelemelerde bulunulan bu davranışlar çoğunlukla insanların yanlış olduğu, başarısız olduğu konularla ilgili olmuştur. İkinci Dünya Savaşından sonra oluşan yıkımların bir sonucu olarak psikolojik çalışmalar daha çok ruhsal bozuklukları çözme yoluna girmiştir. Bundan sonra araştırmacılar yalnızca patolojik sorunlarla ilgilenmenin kişinin ruh sağlığını düzeltmeye yetmeyeceği gibi yaşamı anlamlı ve mutlu kılmaya da yeterli olamayabileceğini ileri sürmüşlerdir (Abramson, Seligman ve Teasdale, 1978). Bildiğimiz klasik psikoloji daima sıfırın altı ile ilgilenmiş, bozuk olanı iyileştirmeye çalışmış ve insanı sıfırın üzerine çıkarmak ise pozitif psikolojinin görevi olmuştur (Tarhan, 2019, s. 20). Pozitif psikoloji; bir insanın kendi imkânları ve potansiyeli dâhilinde ulaşabileceği en yüksek nitelikli hayata, kendine ve etrafındaki kişilere faydalı olabilecek koşullara nasıl ulaşılabileceğini ele alan bir yaklaşımdır (Ok, 2019, s.5)

Ekonomi ve finans alanındaki bildiğimiz kullanımının dışında, "sermaye" kavramı, sosyal sermaye, kültürel sermaye vb. kavramlar içerisinde de yer almaktadır. İşletmelerin varlıklarına dair tanımlar ile bunlara yüklenen önem, yıllar içerisinde değişmiştir (Çınar, 2011). Günümüzün rekabet şartlarında örgütlerin varlıklarını devam ettirebilmeleri, yalnızca verilen görevlerin yerine getirilmesiyle mümkün değildir. Günümüzde örgütler, görev tanımlarında yer almayan ama örgütün başarısını arttıracak farklı durumları ortaya çıkaran, güçlüklerle mücadele edecek ve yaratıcı çalışanlar istemektedirler (Yücel, 2019, s.1137). Gün geçtikçe örgütlerin değerinin yalnızca fiziksel sermaye ve finansal sermaye ile açıklanamayacağı, insan faktörünün örgütlere kattığı değerin göz ardı edilemeyeceği daha da anlaşılmaktadır. İnsan sermayesi ile ilişkilerini ifade eden sosyal sermaye ve pozitif psikolojik sermaye kavramlarının da örgütlere rekabet üstünlüğü kazandırdığı görülmüştür (Yılmaz, 2020, s.72).

İş hayatında rekabet edebilmek için Luthans, Luthans ve Luthans (2004) pozitif psikolojik sermayeyi önermektedir. Ayrıca örgüt içerisinde yapılan basit eğitimlerle kişilerin pozitif psikolojik sermaye seviyelerinin yükselebileceğini, bunun sonucunda iş doyumu ve performanslarda artı̧̧ olabileceğini öne sürmektedirler. Finansal sermayeye nispeten maliyet açısından daha düşük olması pozitif psikolojik sermayenin tercih edilmesi gerektiği anlamına gelmektedir.

Örgüt çalışanlarının kendilerini nasıl tanımladıkları ve algıladıkları araştırılırken ölçülmesi gerekli olan özellikler, pozitif psikolojik sermaye kavramının temel bileşenlerini oluşturmaktadır (Akçay, 2011, s. 80). Pozitif psikolojik sermayeyi Luthans, Youssef ve Avolio (2007b) kapsamlı olarak şu dört boyutta sınıflandırmıştır: (1) Zorlu görevlerde başarılı olmak için gerekli çabayı gösterme ve bu konuda güven duyma (özyeterlik). (2) Şu anda ve gelecekte başarılı olmakla ilgili olumlu inançlara sahip olmak (iyimserlik). (3) Hedeflere doğru devam etmek ve gerektiğinde başarı için yolları hedeflere yönlendirmek (umut). (4) Sorunlar ve sıkıntılarla karşılaşıldığında başarıyı elde etmek için güçlü ve 
dayanıklı olmak (dayanıklılık). Pozitif psikolojik sermayeye ait ilk ölçek de Luthans, Avolio, Avey ve Norman (2007a) aracılığıyla geliştirilmiştir. Bu ölçeğe Tösten ve Özgan (2014) tarafından dışadönüklük ve güven bileşenleri de eklenmiştir. Aşağıda bu altı bileşene yer verilmiştir:

\section{Öz Yeterlilik}

Öz yeterlilik inancı, Bandura'nın geliştirdiği ve kişilerin bilgi ve becerilerini aktif şekilde kullanabilmeleri için, ilk önce, ilgili alanda kendi yeterliliklerine olan inançlarının gerekliliğini ortaya atan sosyal öğrenme kuramına dayanmaktadır (Özerkan, 2007, s. 28; Bolat, 2011, s. 256). Bandura’ya (1986) göre öz yeterlilik, bireyin amaçlarına ulaşması için kendi yeteneklerinin ve kapasitesinin farkına varması ve buna inanmasıdır (Akt. Kutanis ve Oruç, 2014, s. 151). Öz- yeterliği yüksek olan bireyler kendileri için yüksek hedefler belirleyen, zor görevleri kendileri seçen, zorluklarla başa çıkabilen, kendilerini motive edebilen, engellerle karşılaştıklarında sabredebilen bireylerdir (Luthans vd., 2007b). Böyle kişiler verilen bir görevde başarılı olmak için çevrelerini değiştirmek üzere harekete geçme yeteneğine sahip olduklarını algılarlar. Öz-yeterlik performansla ilişkilidir (Clapp-Smith, Vogelgesang ve Avey, 2009). Tian ve Huang'a (2013) göre öz yeterlilik kavramı örgüt çalışanlarının en temel motivasyon kaynağıdır. Yöneticilerin çalışanlarının bu tarz kişisel özelliklerinden doğru bir şekilde yararlanması örgütü hedeflerine götürecek en etkili yollardandır (Erenler Tekmen, Çetin ve Torun, 2016, s. 76). Sonuç olarak, örgütlerde öz yeterlilik inancı yüksek derecede olan çalışanların var olması, örgütün başarıya daha çabuk ve kolay ulaşmasını sağlamada etkili bir faktördür (Üngören ve Ercan, 2015, s. 116).

\section{Umut}

Umut, istenilen hedeflere varabilmek için çeşitli yöntemler geliştirebilme ve bu yöntemleri hayata geçirmek için bireyin kendisini güdülemesi şeklinde tanımlanır. Umut, somut hedefler belirlemeyi, bu hedefler doğrultusunda farklı alternatifler bulabilmeyi ve belirlenen bu hedeflere varabilmek için iradeyi kullanabilmeyi içeren bilişsel bir etkinliktir (Snyder, 2002, akt. Kutanis ve Oruç,2014, s. 152). Umut seviyeleri yüksek düzeyde bulunan kişiler, hedeflerine varabilme arzusunu ve istekliliğini elinde bulundurup, karşı karşıya kalacakları muhtemel güçlükleri tahmin edebilir ve onu hedefine ulaştırabilecek farklı seçenekleri proaktif olarak belirleyebilirler (Akçay, 2012, s. 126). Umut seviyesi yüksek olan kişilerin daha belirli amaçları vardır ve bu durumdan çekinmezler; insanlarla bir arada olmak onlara mutluluk verir; kolaylıkla yeni ve işbirlikçi ilişkiler inşa edebilirler ve çevredeki değişikliklere rahatlıkla uyum sağlayabilirler (Luthans, 2002). Bir görevi başlatma konusunda daha motive olmaları ve bu görev hedeflerine ulaşmak için alternatif yolları öngörmede daha donanımlı olmaları nedeniyle daha yüksek performans sergilemeleri muhtemeldir (Luthans ve Jensen, 2005).

\section{İyimserlik}

İyimserlik kavramı, çok tartışılan ancak az anlaşılan konulardan biridir. Günlük dilde iyimser, gelecekte olumlu ve arzu edilen olayları bekleyen kişidir, kötümser ise sürekli olumsuz düşüncelere sahip olan ve istenmeyen olayların olacağına inanan kişidir (Luthans vd., 2007b). İyimser kişiler karşılaştıkları olaylara iyi veya kötü olsun her zaman pozitif bir bakışla yaklaşırlar, kötümser kişiler ise iyi olaylarla karşılaşsalar bile negatif bakış açısına sahip olmaktadırlar (Hayes ve Weathington, 2007, s.567). İyimserlik, polyannacılık ya da hayata pembe gözlüklerle bakmak değildir tam tersi işlerin iyiye gideceğine dair kendimize olan inanç ve güvendir (Baltaş, 2001, s.185, akt. Hırlak, Taşlıyan ve Sezer, 2017, s. 98). İyimser insanlar elde ettikleri iyi durumların kaynağını kendileri olarak görürken, kötü durumların kaynağını da dış etkenlere bağlarlar ve böylece başarısız oldukları durumlarda karamsarlığa kapılmazlar, özgüvenini korur, umutsuzluğa düşmez ve daima işin sonucunda başarılı olacaklarına inanırlar (Bolat, 2014). Çalışanlarını pozitif düşünmeye teşvik eden örgütler de karşılığında performans artışı elde edebilmektedirler. Bundan dolayı örgüt yöneticilerinin hangi seviyede olurlarsa olsunlar iyimserlik konusuna dikkat çekmesi gerekmektedir (Erdem, 2014, s. 108).

\section{Dayanıklılık}

Pozitif psikolojinin önemli bileşenlerinden biri olan psikolojik dayanıklılık, bireylerin güçlükler karşısında dik durma, mücadele etme ve dayanma gücüdür. Bu güce sahip olanlar, yaşadıkları olumsuz durumlar karşısında çok daha hızlı bir şekilde durumunu düzeltebilmekte ve tekrar eski hayatlarına geri dönebilmektedirler (Karakale ve Kavi, 2018, s. 55). Umut ve öz yeterlilik boyutlarının tersine dayanıklılık boyutu geleceğe yönelik olmak dışında daha tepkici bir kriter olarak karşımıza çıkmaktadır (Berberoğlu, 2013). Dayanıklılıkta karşımıza çıkan iki önemli durum vardır. Bunlardan ilki stresli ve problemli durumlardan kurtulma durumu ile ilgilenirken, ikincisi de bu durumu devam ettirebilmedir. 
Karşılaşılan olumsuz durumlar sonrasında bu durumlarla tekrar tekrar karşılaşıldığında sağlıklı tepkiler vererek yoluna devam etmektir (Savi-Çakar, Karataş ve Çakır, 2014, s. 23-24). Bu durum, zor da olsa psikolojisi sağlam ve güçlü kişilerin pes etmeden defalarca ayağa kalkabildiklerini göstermektedir. Psikolojik dayanıklılık, stresin negatif etkisini aza indirgeyen ve böylelikle hastalıklara sebep olan gerginliği engelleyen kişiye has bir özelliktir. Bu durumda, yüksek psikolojik dayanıklılığa sahip kişiler, işlerine ve gün içerisindeki aktivitelere daha çok bağlanır, yaşamlarını kontrol altında tutar, hiç beklemiyorken gerçekleşen değişiklikleri kendi gelişmeleri açısından firsat şeklinde değerlendirirler. Dayanıkl11ıkları düşük düzeydeki bireylerde ise uzaklaşma, dış kontrol odağı, değişikliklere direnme gibi durumlar görülebilir (Klag ve Bradley, 2004; Maddi ve Khoshaba, 1996, akt. Sezgin, 2012, s. 491).

\section{Güven}

İnsanda doğuştan güven duygusu arayışı olduğunu söyleyen Tarhan (2012), çocuğun doğduğu andan itibaren annesinin kokusunda, sesinde güven aradığını ve buna bağlı olarak insana temel güven duygusunun ilk önce anne tarafindan kazandırıldığını belirtir. Temel güven duygusu oluştukça çocuk bireyselleşir. Kendi kişiliğini oluşturmaya başlar. TDK'ya (2019) göre güven kavramı; korkmadan, çekinmeden veya şüphe duymaksızın inanç, bağlanma ve bireylere itimat etme hissi şeklinde tanımlanır. En kapsamlı manada doğruluk ve dürüstlüğe dayanan bir kavram şeklinde algılanan güvenin, örgütsel başarının olması açısından gerekli olduğu fakat kısa sürede oluşmadığı, uzun ve fedakârlık içeren uğraşlar gerektirmesi hususunda hemfikir olunmuştur (Demircan ve Ceylan, 2003, s. 139). Normal yaşantımızda olduğu gibi örgütlerde de ilişkilerin güvene dayalı olması iş yaşamı kalitesini arttırmaktadır (Memduhoğlu ve Zengin, 2013, s. 212). Güven duygusu fazla olan kişilerin yaşam kalitesi yüksek olduğundan iş yerinde de mutlu oldukları söylenebilir. Bu da kişinin çalışmalarına pozitif yönde yansır. Güven duygusu az olan bireyler ise çalıştıkları ortamda birçok olumsuzlukla karşılaşırlar ve bu yüzden tekrar güven kazanmaları zor olabilir (Sağlam Arı, 2011). Performansı yüksek örgütlerde liderler, kendi içlerinde bulunan güveni, işletmeleri içine yaygınlaştırır. Bunun sonucunda ise, bağlllık ve üretkenlik artışı oluşur. Bu olumlu sonuç, güven duygusunun devamlılığını ve artışını sağlar (Halis, 2018).

\section{Dişadönüklük}

İçinde olduğu platforma kolay bir şekilde uyabilen, çevresiyle iletişim kurma konusunda zorluk yaşamayan ve sosyal ilişkileri kuvvetli olan kişiler dışadönük olarak tanımlanır (TDK, 2019). Dışadönük kişiler girişken, samimi olma, dikkat çekebilme, doğal davranma, aktif, enerjik, insan ilişkisi ve iletişimi kuvvetli olma gibi özelliklere sahiptirler. Bunun tam tersi olan içe dönüklük ise ciddi olma, yalnız kalmayı sevme ve mesafeli durma şeklindeki özellikleri barındırır (İyem ve Erol, 2013, s. 140). İnsanlarla kolay bir şekilde iletişim kurabilen dışadönük bireyler, çalışma hayatında da örgüt için önemli bir yere sahiptirler. Öğretmenlerin dışadönüklük seviyelerinin yüksek olması son derece önemlidir. Çünkü öğretmen, öğrencilerin aile ve diğer çevre ile ilgili sorunlarını çözmede iletişim kolaylığı sağlar ve aile ile arasında sağlam bir köprü kurabilir. Dışadönüklük seviyesi yüksek olan bireylerin iyimserlik seviyelerinin de fazla olduğu ve başka kişi ya da topluluklarla olumlu ilişkiler içerisinde olduğu gözlenmektedir (Tösten ve Özgan, 2014).

\section{Örgütsel Özdeşleşme}

Özdeşleşme, her türlü nitelik bakımından eşit olan, aralarında fark bulunmayan olarak tanımlanmaktadır (TDK, 2019). Örgütsel özdeşleşme kavramı ise, alan yazındaki bazı tanımlar doğrultusunda; kişinin ait olduğu örgütle arasında oluşması istenen bağ olarak görülmüsştür yani kişinin amacı ile örgütün amacının örtüşmesi de denilebilir. (Pratt, 1998, akt. Tüzün ve Çağlar, 2008). Bilişsel bir süreç olan özdeşleşme ile ilgili başlıca öğeler; kişinin örgüt amaç ve değerlerine olan güçlü inanc1, kişinin örgüt içerisindeki rolünü oluşturan eylemleri kendi isteğiyle yerine getirmesi ve bireyin bağlı olduğu kuruma üyeliğinin devamı konusunda arzulu olmasıdır. Ayrıca, bu öğelerdeki pozitif doğrulamaların gücü, bireyin işten ayrılma niyetini azaltmakta veya ortadan kaldırmaktadır (Sığrı ve Gürbüz, 2015, s. 73, akt. Aktaş, 2019). Bunun yanında örgütle özdeşleşen kişi, örgüte faydası olacak davranışların kendisi için de faydalı olacağına inandığından dolayı (Dukerich vd., 2002, s. 511; Fettahoğlu ve Koca, 2014), örgütünü daha çok düşünür ve örgüt lehine daha çok gayret göstermeye başlar (Christ vd., 2003, s. 331; İşcan 2006, s. 161; akt. Fettahoğlu ve Koca, 2014).

Örgüt üyelerinin birbirlerine karşı olan bağl1lığ 1 , olumlu etkileşimlerle birlikte uyumsuzlukların ortadan kalkması durumu özdeşleşmeyi meydana getirir. Özdeşleşme; bireyin, örgüt içerisindeki memnuniyetini, faaliyetlere duyduğu ilgisini, grup içerisinde bulunan herkesi eşit değerde görmesini ve 
bu bireylerle uyum içerisinde çalışmasını sağlamaktadır. Örgüt içinde bulunan duyguların yeniden tanımlanmasıyla birlikte, sadakat, bağl1lık gibi hisler güçlenir. Örgüte yeni dahil olan üyeler de bu şekilde örgüte daha kolay alışmaktadırlar (Mael ve Ashford, 1989, s. 35, akt. Çevik,2019).

\section{Araştırmanın Amacı}

$\mathrm{Bu}$ araştırmanın temel amacı, ortaokullarda görev yapan öğretmenlerin pozitif psikolojik sermaye düzeyleri ile örgütsel özdeşleşmeleri arasında bir ilişki bulunup bulunmadığını saptamaktır. Bu amacı gerçekleştirebilmek için aşağıdaki sorulara cevap aranmıştır:

1. Ortaokul öğretmenlerinin pozitif psikolojik sermaye algıları ne düzeydedir?

2. Ortaokul öğretmenlerinin örgütsel özdeşleşme algıları ne düzeydedir?

3. Ortaokul öğretmenlerinin pozitif psikolojik sermaye ve örgütsel özdeşleşme algıları arasındaki ilişki ne düzeydedir?

4. Öğretmenlerin pozitif psikolojik sermaye düzeyleri, örgütsel özdeşleşme düzeylerini anlamlı olarak açıklamakta mıdır?

\section{Yöntem}

Ortaokul öğretmenlerinin pozitif psikolojik sermaye ile örgütsel özdeşleşme algıları arasındaki ilişkinin belirlenmesi amaçlanan bu çalışmada ilişkisel tarama modelinden yararlanılmıştır. İlişkisel tarama modeli, iki ya da daha fazla değişken arasındaki ilişkileri belirlemek ve ilişkinin yönünü, gücünü ve etkisini ortaya koymak amacıyla yapılan araştırmalardır (Büyüköztürk, Kılıç Çakmak, Akgün, Karadeniz ve Demirel, 2014).

\section{Evren ve Örneklem}

Araştırmanın evreni, Millî Eğitim Bakanlığı Antalya ili Kepez İlçe Milli Eğitim Müdürlüğüne bağl1 ortaokullarda 2018-2019 eğitim-öğretim yılında görev yapan 1893 öğretmenden oluşturmaktadır. Evreni temsil edecek örneklem sayısını belirlerken Gay ve Airasian (1999) tarafından düzenlenmiş evren-örneklem tablosundan yararlanılmıştır. Söz konusu tabloya göre örneklemin 317 ile 320 arasında olması gerekmektedir. Bu sayıya ulaşmak için basit tesadüfi örnekleme tekniği ile 351 öğretmenden ölçek toplanmıştır. Bu ölçeklerden ise hatalı ve eksik doldurulanlar çıkarılmış ve toplam 331 ölçek analizlere dahil edilmiştir.

Tablo 1

Araştırmaya Katılan Öğretmenlere Ait Bilgiler

\begin{tabular}{llll}
\hline & & Frekans & $\%$ \\
\hline Cinsiyet & Kadın & 207 & 62.5 \\
& Erkek & 124 & 37.5 \\
& 5 yıldan az & 64 & 19.3 \\
& $6-10$ yıl & 108 & 32.6 \\
& $11-15$ yıl & 100 & 30.2 \\
Çalıştıkları okuldaki görev süresi & 16 yıl ve üstü & 59 & 17.8 \\
& 1 yıl ve altı & 67 & 20.2 \\
Çalıştıkları okuldaki öğretmen sayısı & 2-4 yıl & 151 & 45.6 \\
& 5 yıl ve üstü & 113 & 34.1 \\
& 30 ve altı & 61 & 18.4 \\
Okulun öğretim türü & $31-45$ öğretmen & 124 & 37.5 \\
& 46 ve üstü & 146 & 44.1 \\
& Normal öğretim & 224 & 67.7 \\
\hline
\end{tabular}

\section{Veri Toplama Araçları}

Araştırmanın verileri Pozitif Psikolojik Sermaye Ölçeği ve Örgütsel Özdeşleşme Ölçeği kullanılarak toplanmiştır.

Pozitif Psikolojik Sermaye Ölçeği: Öğretmenlerin pozitif psikolojik sermayelerine ilişkin algılarını belirlemek için Tösten ve Özgan (2014) tarafindan geliştirilen Pozitif Psikolojik Sermaye Ölçeği kullanılmıştır. Pozitif Psikolojik Sermaye Ölçeği toplam altı boyuttan ve 26 maddeden oluşmaktadır. Beşli likert tipi olan ölçek soldan sağa doğru Hiç katılmıyorum seçeneği 1 puan, Az Katıllyorum seçeneği 2 puan, Kararsızım seçeneği 3 puan, Çoğunlukla Katıllyorum seçeneği 4 puan, Tamamen Katıllyorum 
seçeneği 5 puan şeklinde derecelendirilmiştir. Ölçekte ters puanlanan madde bulunmamaktadır. Pozitif psikolojik sermaye ölçeğinin boyutları ise 1.2.3.4. maddeler "özyeterlilik", 5.6.7.8.9. maddeler "iyimserlik", 10.11.12.13. maddeler "güven", 14.15.16.17.18. maddeler "dışadönüklük", 19.20.21.22.23. maddeler "psikolojik dayanıklılık", 24.25.26. maddeler ise "umut" olarak belirlenmiştir. Altı boyutlu ölçeğin orjinalinden elde edilen puanlar için hesaplanan alfa iç tutarlılık katsayısı özyeterlilik boyutu için .80 , iyimserlik boyutu için .80 , güven boyutu için .83 , dişadönüklük boyutu için .79 , psikolojik dayanıklılık boyutu için .76 ve umut boyutu için .73' dir. Altı boyutlu ölçeğin Cronbach Alpha güvenirlik katsayısı " 0.93 " olarak hesaplanmıştır.

Örgütsel Özdeşleşme Ölçeği: Öğretmenlerin örgütsel özdeşleşme düzeylerine yönelik algılarını belirlemek amacıyla Örgüsel Özdeşleşme Ölçeği’nden yararlanılmıştır. Mael ve Ashforth (1992) tarafindan geliştirilen ve Şahin (2014) tarafindan Türkçeye uyarlanan ölçek tek boyut ve toplam altı maddeden oluşmaktadır. Ölçek puanlamasında, Hiç Katılmıyorum seçeneği 1 puan, Az Katıliyorum seçeneği 2 puan, Orta Düzeyde Katıllyorum seçeneği 3 puan, Oldukça Katıllyorum seçeneği 4 puan ve Tamamen Katıllyorum seçeneği 5 puan olarak değerlendirilmektedir. Ölçekte ters puanlanan madde bulunmamaktadır. Ölçeğin orjinalinde Cronbach Alfa iç tutarlık katsayı değeri 0.86 olarak hesaplanmiştır.

\section{Verilerin Toplanması}

Araştırmanın verileri toplanmadan önce gerekli izinler alınmıştır. Veriler, 2018-2019 öğretim yılında toplanmıştır. Veri toplama sürecinde, okullara bizzat gidilmiş ve öğretmenler bilgilendirilmiştir. Öğretmenlerin ölçeği gönüllülük esasına göre doldurması sağlanmıştır.

\section{Verilerin Analizi}

Pozitif Psikolojik Sermaye Ölçeği ve Örgütsel Özdeşleşme Ölçeği ile toplanan veriler bir paket program aracılığ ile analiz edilmiştir. Verilerin analizine geçmeden önce normal dağılma durumlarına bakılmış ve hangi testlerden yararlanılacağına karar verilmiştir. Verilerin normal dağılım gösterip göstermeme durumu, çarpıklık (skewness) ve basıklık (kurtosis) katsayılarına bakılarak test edilmiştir.

Tablo 2

Pozitif Psikolojik Sermaye ve Örgütsel Özdeşleşme-Alt Boyutlarına İlişkin Çarpıklık- Basılklk Değerleri

\begin{tabular}{lll}
\hline & Çarpıklık & Basıklık \\
\hline Özyeterlilik & -.602 & -.062 \\
İyimserlik & -1.020 & 1.012 \\
Güven & -1.013 & .607 \\
Dişadönüklük & -.826 & .704 \\
Dayanıkl1lık & -.622 & .259 \\
Umut & -.743 & .526 \\
Özdeşleşme & -.247 & -.795 \\
\hline
\end{tabular}

Tablo 2'de de görüldüğü gibi çarpıklık ve basıklık değerleri -.1.02 ile +1.01 aralığında değişmektedir. Bu değerler \pm 2.0 aralığında olduğu için verilerin normal dağılım gösterdiği kabul edilmiş (George ve Mallery, 2010) ve analizlerde parametrik testlerden yararlanılmıştır.

Veriler analiz edilirken frekans, aritmetik ortalama, standart sapma ile korelasyon ve çoklu regresyon analizinden faydalanılmıştır. İliş̧ki düzeyinin yorumlanmasında " 0.70 ile 1.00 arası yüksek, 0.69 ile .30 arası orta ve 0.29 ile 0.00 arası ise düşük ilişki" olarak ele alınmıştır (Büyüköztürk, 2012). Öğretmenlerin pozitif psikolojik sermaye düzeylerine ilişkin algılarının örgütsel özdeşleşmelerini yordayıp yordamadığını saptamak için çoklu regresyon analizinden yararlanılmıştır. Tüm analizlerde anlamlılık düzeyi 0.05 ve 0.01 olarak alınmıştır.

Aritmetik ortalamaların yorumlanmasında aralıklar Pozitif Psikolojik Sermaye Ölçeği için; 4.20 - 5.00 "tamamen katılıyorum", 3.40 - 4.19 "çoğunlukla katılıyorum", 2.60 - 3.39 "kararsızım", $1.80-2.59$ "az katılıyorum", 1 - 1.79 "hiç katılmıyorum" olarak değerlendirilmiştir. Örgütsel özdeşleşme için ise, 4.20 - 5.00 "tamamen katılıyorum", 3.40 - 4.19 "oldukça kat1lıyorum", 2.60 - 3.39 "orta düzeyde katılıyorum", 1.80 - 2.59 "az katılıyorum", 1 - 1.79 "hiç katılmıyorum" olarak belirlenmiştir.

\section{Bulgular}


Öğretmenlerin pozitif psikolojik sermaye ve örgütsel özdeşleşmeye yönelik algılarını betimleyen ortalama ve standart sapma değerleri ile katılım düzeyleri tablo 3 ve 4 'te verilmiştir.

Tablo 3

\begin{tabular}{lcccl}
\multicolumn{5}{c}{ Pozitif Psikolojik Sermaye ve Alt Boyutlarına İlişkin Öğretmen Algılarını Betimleyen Değerler } \\
\hline İyimserlik & $\mathrm{N}$ & $\mathrm{X}$ & $\mathrm{SS}$ & Katılım Düzeyi \\
Dayanıklılık & 331 & 4.16 & .73 & Çoğunlukla katılıyorum \\
Dişadönüklük & 331 & 4.29 & .57 & Tamamen katıllyorum \\
Umut & 331 & 4.35 & .56 & Tamamen katıllyorum \\
Özyeterlilik & 331 & 4.38 & .57 & Tamamen katılıyorum \\
Güven & 331 & 4.42 & .51 & Tamamen katıllyorum \\
Genel PPS & 331 & 4.61 & .44 & Tamamen katıllıorum \\
\hline
\end{tabular}

Tablo 3'teki değerler incelendiğinde araştırmaya katılan öğretmenlerin pozitif psikolojik sermaye ve alt boyutlarındaki maddelere verdikleri yanıtların ortalaması en az 4.16 ve en fazla 4.61 olarak bulunmuştur. Öğretmenler iyimserlik boyutuna "Çoğunlukla Katılıyorum" yanıtını verirken diğer beş alt boyuta "Tamamen Katılıyorum" şeklinde yanıt vermiştir. Öğretmenlerin bu ölçekte en yüksek algıya sahip oldukları ve "Tamamen Katılıyorum" düzeyinde cevaplandırdıkları alt boyut güven alt boyutuyken (X=4.61), bu ölçeğin en düşük ortalamaya sahip ve "Çoğunlukla katıllyorum" düzeyinde cevaplandırılan alt boyutu ise iyimserlik alt boyutu $(X=4.16)$ olarak görülmektedir. Genel olarak bakıldığında ise öğretmenlerin pozitif psikolojik sermaye algılarının oldukça yüksek olduğu gözlemlenmektedir.

Tablo 4

Örgütsel Özdeşleşmeye İlişkin Ö̆gretmen Algılarını Betimleyen Değerler

\begin{tabular}{lllll}
\hline Örgütsel Özdeşleşme & N & X & SS & Katılım Düzeyi \\
\hline Genel & 331 & 3.44 & .96 & Çoğunlukla katıllıyorum
\end{tabular}

Tablo 4'te verilen değerler incelendiğinde, araştırmaya katılan öğretmenlerin örgütsel özdeşleşme algılarına ilişkin puan ortalamalarının 3.44, katılım düzeylerinin ise "Çoğunlukla katılıyorum" düzeyinde olduğu görülmüştür.

Tablo 5

Öğretmenlerin Pozitif Psikolojik Sermaye ve Alt Boyutları ile Örgütsel Özdeşleşme Algıları Arasındaki İlişki (Korelâsyon Analizi)

\begin{tabular}{lcccccccc} 
& 1 & 2 & 3 & 4 & 5 & 6 & 7 & 8 \\
\hline Özyeterlilik(1) & 1 & & & & & & & \\
İyimserlik(2) & $0.560^{*}$ & 1 & & & & & & \\
Güven(3) & $0.647^{*}$ & $0.497^{*}$ & 1 & & & & & \\
Dişadönüklük(4) & $0.605^{*}$ & $0.537^{*}$ & $0.682^{*}$ & 1 & & & & \\
Dayanıkl111k(5) & $0.533^{*}$ & $0.523^{*}$ & $0.576^{*}$ & $0.697^{*}$ & 1 & & & \\
Umut(6) & $.495^{*}$ & $0.421^{*}$ & $0.481^{*}$ & $0.575^{*}$ & $0.719^{*}$ & 1 & & \\
Genel PPS(7) & $0.780^{*}$ & $0.790^{*}$ & $0.778^{*}$ & $0.853^{*}$ & $0.844^{*}$ & $0.739^{*}$ & 1 & \\
Örgütsel Özdeşleşme(8) & $0.197^{*}$ & $0.389^{*}$ & $0.291^{*}$ & $0.346^{*}$ & $0.382^{*}$ & $0.358^{*}$ & $0.420^{*}$ & 1 \\
\hline *p $<.01$ & & & & & & & &
\end{tabular}

Tablo 5 incelendiğinde öğretmenlerin pozitif psikolojik sermaye ve örgütsel özdeşlemeleri arasındaki ilişkiye bakıldığında örgütsel özdeşleşmelerinin öz yeterlilik ( $\mathrm{r}=0.197)$ ve güven $(\mathrm{r}=0.291)$ alt boyutuyla aralarında pozitif yönde düşük düzeyde ilişkiye sahip olduğu görülürken, diğer (iyimserlik, dışadönüklük, dayanıklılık ve umut) alt boyutlarıyla ise pozitif yönde orta düzeyde bir ilişki içerisinde olduğu görülmektedir. Öğretmenlerin genel pozitif psikolojik sermaye düzeyleri ile örgütsel özdeşleşme 
algıları arasındaki ilişkiye bakıldığında $(\mathrm{r}=0.420, \mathrm{p}<0,01)$ pozitif yönde, orta düzeyde bir ilişki bulunduğu görülmektedir.

Tablo 6

Öğretmenlerin Pozitif Psikolojik Sermayelerinin Örgütsel Özdeşleşmelerini Yordama Düzeyi (Regresyon Analizi)

\begin{tabular}{llllll} 
Değişkenler & $\mathrm{B}$ & Standart Hata & Beta & $\mathrm{t}$ & $\mathrm{p}$ \\
\hline Sabit & .122 & .519 & & .235 & .814 \\
Özyeterlik & -.402 & .133 & -.215 & -3.030 & $.003^{* *}$ \\
İyimserlik & .379 & .082 & .290 & 4.597 & $.000^{* *}$ \\
Güven & .167 & .160 & .077 & 1.045 & .297 \\
Dişadönüklük & .155 & .138 & .090 & 1.126 & .261 \\
Dayanıkl1lı & .199 & .138 & .120 & 1.442 & .150 \\
Umut & .279 & .122 & .165 & 2.292 & $.023^{*}$ \\
\hline$R=.478$ & $R^{2}=.229$ & & & \\
$F_{(6-324)}=16.002$ & $P=.000$ & & &
\end{tabular}

Tablo 6'daki bulgular, yordayıcı değişkenler yani pozitif psikolojik sermayenin alt boyutları (özyeterlik, iyimserlik, güven, dışa dönüklük, dayanıklık ve umut) bir arada düşünüldüğünde oluşturulan modelin anlamlı çıktığını göstermektedir $(\mathrm{p}<.01)$. Pozitif psikolojik sermayenin tüm alt boyutlarının doğrusal kombinasyonunun öğretmenlerin örgütsel özdeşleşmelerini anlamlı olarak yordadığ $1\left(\mathrm{R}=.478 ; \mathrm{R}^{2}=.229\right)$ görülmektedir $\left[\mathrm{F}_{(6-324)}=16.002 ; \mathrm{p}<0.01\right]$. Pozitif psikolojik sermayenin alt boyutları, örgütsel özdeşleşmeye ait varyansın \%23 'ünü açıklamaktadır. Öğretmenlerin örgütsel özdeşleşmelerinin \%23' ü pozitif psikolojik sermayenin iyimserlik, özyeterlilik, umut, dayanıklılık, dışadönüklük ve güven boyutlarına yönelik algılar ile açıklanabilmektedir. Pozitif psikolojik sermayenin iyimserlik, özyeterlilik, umut, dayanıklılık, dışadönüklük ve güven boyutları puanlarının bağımsız, örgütsel özdeşleşme puanının bağımlı değişken olarak alındığı regresyon analizi istatistiksel olarak anlamlıdır $(p<0.01)$. Standardize edilmiş regresyon katsayısı $(\beta)$ incelendiğinde, yordayıcı değişkenlerin örgütsel özdeşleşme üzerindeki göreli önem sırası iyimserlik, özyeterlilik, umut, dayanıklılık, dışadönüklük ve güvendir.

Regresyon katsayısının anlamlılığına ilişkin $t$ testi sonuçları incelendiğinde öğretmenlerin örgütsel özdeşleşmeleri üzerinde özyeterlilik, iyimserlik ve umut boyutlarının etkilerinin anlamlı olduğu bulunmuştur. Yani özyeterlilik, iyimserlik ve umut boyutları tek başına öğretmenlerin örgütsel özdeşleşmelerini anlamlı olarak açıklamaktadır.

\section{Tartışma}

$\mathrm{Bu}$ çalışmanın amacı, öğretmenlerin algılarına göre pozitif psikolojik sermaye ve örgütsel özdeşleşmeleri arasındaki ilişkiyi incelemektir. $\mathrm{Bu}$ amaç doğrultusunda elde edilen sonuçlara göre öğretmenlerin genel pozitif psikolojik sermayelerine ilişkin algılarının çok yüksek çıktığı söylenebilir. Öğretmenlerin pozitif psikolojik sermayelerine ilişkin algıları boyutlar bazında incelendiğinde, güven algılarının çok yüksek olduğu ve alt boyutlar arasında en yüksek düzeyde yanıt verdikleri boyut olduğu görülmüş; iyimserlik algılarının ise yüksek olduğu fakat alt boyutlar arasında daha az ortalamaya sahip olduğu bulunmuştur. Öğretmenlerin genel örgütsel özdeşleşmelerine ilişkin algılarının ise yüksek olduğu sonucuna ulaşılmıştır.

Öğretmenlerin pozitif psikolojik sermayenin geneline ilişkin algıları incelendiğinde, öğretmenlerin pozitif psikolojik sermayeye ilişkin algılarının çok yüksek olduğu görülmektedir. Bu bulguyu destekler nitelikte, Sarıc1 (2015), Aslan (2017), Barut (2017), Ekin (2019), Şimşek (2018), Erbaş (2018), Yıldırım (2019) ve Çiftçi (2019) benzer sonuçlara ulaşmışlardır. Yapılan araştırma sonucunda elde edilen bu sonuç, istenen bir sonuçtur çünkü pozitif psikolojik sermaye düzeyleri arttırılan öğretmenler okul başarı 
düzeyini önemli oranda etkileyebilir. Bir eğitim kurumunun başarılı olabilmesi için öğretmenin verimli ve kaliteli bir eğitim verebilmesi gereklidir. Fakat öğretmen ne kadar nitelikli olursa olsun, psikolojik durumu mesleğinde başarılı olup olmamasını etkilemektedir (Kelekçi ve Yılmaz, 2015). Örgütlerde genellikle çalışanlarda bulunan mevcut potansiyellere ve zayıf olan taraflarının düzeltilmesine odaklanılmakta, onların güçlü yönleri veya potansiyelleri görmezden gelinmektedir. Ancak örgütlerin rekabet üstünlüğünün devamını sağlamak, örgüt çalışanlarında performans artışını sağlamak, çalışanların kendi yeteneklerinin farkına varmalarını sağlayarak onları geliştirmek için pozitif bir yaklaşıma ihtiyaç vardır (Kutanis ve Oruç, 2014). Günümüzdeki örgütlerde, çalışanların daha çok kıymetli olmaya başlaması ve örgütlerin çalışanlarını değerli hissettirmeye çalışmaları bu konuyu önemli bir duruma getirmiştir (Yazar ve Özutku, 2019). Bu konuda örgütlerin üzerine düşen görev, pozitif psikolojik sermayenin kuvvetine inanmaktır. Pozitif psikoloji yalnızca birey değil, örgüt içerisindeki herkes üzerinde pozitif etki yaratabilir. Bu nedenle, örgüt çalışanlarının pozitif tarafları üzerinde durulmalı ve mevcut potansiyellerinin meydana çıkmasına yardımcı olunmalıdır (A $\breve{g}$ ve Balcı, 2018). Luthans ve Youssef (2004), psikolojik sermayenin çalışanların sosyal hayatında güvenini, umudunu, iyimserliğini ve esnekliğini şekillendirdiğini ve örgütlerin bu psikolojik unsurları çok büyük bir alternatif olarak göz önünde bulundurmalarının etkili bir iş performansı sağlama konusunda önemli bir yerinin olduğunu belirtmektedir. Luthans, Norman, Avolio ve Avey (2008), yaptıkları çalışmalarında, çalışanların pozitif psikolojik sermayelerinin destekleyici örgütsel iklim ile çalışan performansları arasındaki ilişkiye aracılık ettiğini görmüştür. Avey, Luthans, Smith ve Palmer (2010), pozitif psikolojik sermayenin çalışanların refah seviyeleri ile pozitif yönde ilişkili olduğu sonucuna ulaşmışlar. Avey, Reichard, Luthans ve Mhatre (2011) pozitif psikolojik sermaye ile istenilen çalışan tutumları, istenilen çalışan davranışları ve performansa yönelik çoklu ölçümler arasında pozitif yönde ilişkiler olduğu; psikolojik sermaye ile istenilmeyen çalışan davranışları ve tutumları arasında da anlamlı bir negatif ilişki bulunduğu sonucuna ulaşmışlardır.

Öğretmenlerin pozitif psikolojik sermayeye dair algıları incelendiğinde, güven boyutuna en yüksek, iyimserlik boyutuna ise en düşük katılım gerçekleştiği görülmektedir. Bu çalışmanın sonuçlarına benzer şekilde Sarıcı (2015), Tösten (2015), Aslan (2017), Barut (2017), Şimşek (2018), Erbaş (2018), Ekin (2019), Demir (2019), Seçilmiş (2019) ve Yıldırım'ın (2019) çalışmalarında da öğretmenlerin güven algılarının en yüksek, iyimserlik algılarının ise en düşük olduğu sonucuna ulaşmışlardır. En yüksek ortalamanın güven alt boyutuna ait olması, öğretmenlerin görev ve sorumluluklarının bilincinde olması, yöneticileri tarafından kararlara dâhil edilmeleri ve cesaretlendirilmeleri, daha önceki başarıları vs. gibi nedenlerle açıklanabilir. Ayrıca öğretmenlerin mesleğini icraat ederken kullanacakları yöntem, teknik ve stratejilerdeki mesleki özgürlükleri, denetim uygulamalarındaki şeffaflık da öğretmenlerin yüksek güven düzeyine sahip olmalarında etkili faktörler olabilir. Carver ve Scheier (2002, s. 231) güven seviyesi yüksek olan kişilerin motivasyonlarının da yüksek olacağını ve bu nedenle hedefe daha istikrarlı gideceklerini ifade etmektedir (Akt. Tösten ve Özgan, 2017). Öğretmenlerin yüksek güven duygusuna sahip olmalarının hem öz yeterliliklerini arttırırken hem de öğrencilerinin özgüven duygusuna sahip olmalarına katkı sağladığı söylenebilir (Uysal ve Gürol, 2018). Güven kavramı, toplumsal yaşantımızda olduğu kadar örgüt yaşamında da çok önemli bir kavramdır. Aktif ve başarılı olmayı arzulayan tüm örgütler güven ortamı sağlamak durumundadır. Güven ortamının sağlandığı ortamlarda karmaşık ve belirsiz olma durumu ile zarar görme olasılığı azalır (Kartal, 2010). Genel olarak bakıldığında örgütler yönünden hedefler, yöntemler, normlar vb. ile takım oluşturma ve güdüleme çalışmaları, aslında örgüt çalışanları arasında var olduğu farz edilen güven temeline dayandırılmaktadır. Fakat güvenin yetersiz olma durumu, bahsedilen etkinliklerden istenilen sonuçların gerçekleşmemesine neden olabilmektedir (Asunakutlu, 2001). Bu durum göz önünde bulundurulduğunda okul içerisindeki çalışanların yüksek motivasyonlu, iş birliği yapabilen, güvenen ve güven verme konusunda kendilerinden emin olan bireyler olmaları halinde örgütün daha başarılı olacağı söylenebilir.

Araştırmaya katılan öğretmenlerin örgütsel özdeşleşmelerine yönelik algıları incelendiğinde, öğretmenlerin örgütleri ile özdeşleşmelerinin yüksek olduğu sonucu çıkarılabilir. Örgütlerin başarısı yalnızca çalışanların yeterliliği ve performansları ile değil, yüksek performansa sahip iş gücünün çalıştıkları örgüte bağl1 kalmasını sağlamakla mümkündür (Arı, 2003). Bireyler ait oldukları örgütlerinin davranış biçimlerini benimsiyorlar, kendilerini o örgüte bağlı durumda hissediyorlar ise özdeşleşme var demektir (Balay, 2000). Örgütle özdeşleşen kişi, örgüte faydası olacak davranışların kendisi için de faydalı olacağına inandığından dolayı, örgütünü daha çok düşünür ve örgüt lehine daha çok gayret göstermeye başlar (Dukerich vd., 2002; Christ vd., 2003; İşcan 2006, akt. Fettahoğlu ve Koca, 2014). 
Outten, Schmitt, Garcia, ve Branscombe (2008) araştırmaları sonucunda grupla özdeşleşmenin öz sayg1 ve yaşam doyumu ile ilişkili olduğunu ve psikolojik iyi oluşu pozitif yönde yordadığını bulmuşlardır. Lu, Liu, Sui ve Wang'ın (2015) araştırmalarında ise örgütsel özdeşleşme ve iş tatmini arasında pozitif yönde bir ilişki bulunmuştur.

Araştırmada son olarak öğretmenlerin pozitif psikolojik sermayelerine ilişkin algılarının örgütsel özdeşleşmelerine ilişkin algılarını anlamlı olarak açıklayıp açıklamadığına bakılmıştır. Pozitif psikolojik sermayenin alt boyutları (özyeterlik, iyimserlik, güven, dışa dönüklük, dayanıklık ve umut) bir arada düşünüldüğünde örgütsel özdeşleşmeyi anlamlı olarak yordadığı sonucuna ulaşılmıştır. Bu bulgudan hareketle, öğretmenin pozitif psikolojik sermaye düzeylerinin arttırılması yönünde çalışmalar yapıldığında örgütleriyle özdeşleşme düzeylerinin artacă̆ 1 söylenebilir. Öğretmenlerin pozitif psikolojik sermayelerine yapılan yatırımlar sonucu, kendilerine değer veren bir okulda çalışıyor olduklarını bilmeleri, onların daha rahat ve huzurlu hissetmelerini sağlayacağı gibi aynı zamanda da okulu benimsemeleri hususunda önemli bir etken olduğu söylenebilir. Öğretmenler kendi çıarları ve okulun çıkarlarının örtüşmesi sonucu ile kendilerini okulla birlikte bir ekip olarak görür ve eğitimde kalite artışı sağlanabilir. Bundan dolayı, Erkuş ve Fındıklı (2013), insan kaynaklarının ele alınmasının yanında, örgüt çalışanlarının psikolojik sermaye seviyelerini arttıracak uygulamaların gündeme getirilmesi gerektiğini belirtmiş̧lerdir. Erdem ve arkadaşları (2015), psikolojik sermayenin örgütsel özdeşleşme üzerindeki etkisi ve algılanan örgütsel desteğin aracılık rolünü belirlemeyi amaçladığ1 çalışmalarında örgütsel özdeşleşme ve psikolojik sermaye arasında pozitif yönlü bir ilişki bulmuşlardır.

\section{Kaynakça}

Abramson, L.Y., Seligman, M.E., \& Teasdale, J.D. (1978). İnsanlarda öğrenilmiş çaresizlik: Eleştiri ve reformülasyon. Anormal Psikoloji Dergisi, 87(1), 49-74.

Ağ, C., \& Balcı, O. (2018). Psikolojik örgütsel sermayenin merak ve keşfetme ile ilişkisi: Bir bilişim sektörü örneği. International Social Sciences Studies Journal, 4(24), 5173-5180.

Akçay, H.V. (2011). Pozitif psikolojik sermaye kavramı ve işletmelerde sürdürülebilir rekabet üstünlüğünü sağlamadaki rolü. Gazi Üniversitesi İktisadi ve İdari Bilimler Fakültesi Dergisi, 13(1), 73-98.

Akçay, V. (2012). Pozitif Psikolojik Sermayenin İş Tatmini ile İlişkisi. Kahramanmaraş Sütçü İmam Üniversitesi İktisadi ve İdari Bilimler Fakültesi Dergisi, 2(1), 123-140. http://iibfdergisi.ksu.edu.tr/tr/pub/issue/10264/125890

Akman, Y. (2017). Öğretmenlerin algılarına göre iş motivasyonu ve örgütsel özdeşleşme arasındaki ilişki. Hasan Ali Yücel Ĕ̈itim Fakültesi Dergisi, 14-1(27), 71-88.

Aktaş, K. (2019) İşgörenlerin adanmışlık düzeyi ve örgütsel özdeşleşme ilişkisinin performans algısına etkisini belirlemeye yönelik bir araştırma. (Yayınlanmamış Doktora Tezi). İnönü Üniversitesi Sosyal Bilimler Enstitüsü. Malatya

Ar1, G. S., (2003). Yöneticiye duyulan güven örgütsel bağlılı̆̆1 arttırır mı?. Gazi Üniversitesi Ticaret ve Turizm Eğitim Fakültesi Dergisi, 2(2), 17-36.

Arı, G.S. (2011). Kadın ve erkek yöneticilerin güven özelliklerine ilişkin tutumları: Varsayımsal astlar üzerine bir araştırma. Atatürk Üniversitesi Sosyal Bilimler Enstitüsü Dergisi, 15(1), 105-120.

Aslan, İ. (2017). Öğretmenlerin pozitif psikolojik sermaye algıları ile örgütsel bağl1lıkları arasındaki ilişkinin incelenmesi. (Yayımlanmış Yüksek Lisans Tezi). Siirt Üniversitesi Sosyal Bilimler Enstitüsü. Siirt

Asunakutlu, T. (2001). Klasik ve neo-klasik dönemde örgütsel güvenin karşılaştırılması üzerine bir deneme. Muğla Üniversitesi Sosyal Bilimler Enstitüsü Dergisi, (5), 0-0. https://dergipark.org.tr/tr/pub/musbed/issue/23531/250717

Avey, J.B., Luthans, F., Smith, R. M.\& Palmer, N.F., (2010). Impact of positive psychological capital on employee well-being over time. Journal of Occupational Health Psychology, 15(1), 17-28. 
Avey, J.B., Reichard, R.J., Luthans, F., \& Mhatre, K.H., (2011). Meta-analysis of the impact of positive psychological capital on employee attitudes, behaviors, and performance. Human Resource Development Quarterly, 22(2), 127-152.

Balay, R. (2000). Yönetici ve ögretmenlerde örgütsel bă̆lllık. Ankara: Nobel Yayınları.

Barut, A. (2017). Öğretmenlerin işyeri ruhsallığı ile pozitif psikolojik sermaye algıları arasındaki ilişkinin incelenmesi. (Yayımlanmamış Yüksek Lisans Tezi). Gaziantep Üniversitesi Eğitim Bilimleri Enstitüsü. Gaziantep

Berberoğlu, N. (2013). Psikolojik sermayenin örgütsel vatandaşlık davranışı üzerine etkisi: Bir alan araştırması. (Yayımlanmamış Yüksek Lisans Tezi). Gazi Üniversitesi Sosyal Bilimler Enstitüsü. Ankara

Bolat, O. (2011). Öz yeterlik ve tükenmişlik ilişkisi: Lider- üye etkileşiminin aracılık etkisi. Ege Akademik Bakış Dergisi, 11 (2), 255-266.

Bolat, Ö. (2014, 13 Şubat). İyimser insanlar neden başarılı olur? https://www.hurriyet.com.tr/iyimserinsanlar-neden-basarili-olur-25798731 adresinden 15.05.2020 tarihinde alınmıştır.

Büyüköztürk, Ş. (2012). Sosyal bilimler için veri analizi el kitabı. Ankara: Pegem Akademi.

Büyüköztürk, Ş., Kılıç Çakmak, E., Akgün, Ö.E., Karadeniz, Ş., \& Demirel, F. (2014). Bilimsel araştırma yöntemleri. (17. Bask1). Ankara: Pegem.

Clapp-Smith, R., Vogelgesang, G. R., \& Avey, J. B. (2009). Authentic leadership and positive psychological capital: The mediating role of trust at the group level of analysis. Journal of Leadership \& Organizational Studies, 15(3), 227-240.

Çevik, S. (2019). Futbol takımlarındaki örgütsel özdeşleşme ve örgüt kültürünün takım başarısı üzerindeki etkisinin incelenmesi (TFF 1. lig örneği). (Yayımlanmamış Yüksek Lisans Tezi). Manisa Celal Bayar Üniversitesi Sosyal Bilimler Enstitüsü. Manisa

Çınar, E. (2011). Pozitif psikolojik sermayenin örgütsel bağlılıkla ilişkisi. (Yayımlanmamış Yüksek Lisans Tezi). Dokuz Eylül Üniversitesi Sosyal Bilimler Enstitüsü. İzmir

Çiftçi, K. (2019). Pozitif psikoloji bağlamında sınıf öğretmenlerinin psikolojik iyi oluş düzeyleri ile özyeterlik inançları ve örgütsel bağlılık davranışları arasındaki ilişkinin incelenmesi. (Yayınlanmamış Yüksek Lisans Tezi). Sakarya Üniversitesi Eğitim Bilimleri Enstitüsü. Sakarya

Demir, E. (2019). Öğretmenlerin iş yaşam kalitesi ile pozitif psikolojik sermaye düzeyleri arasındaki ilişkinin incelenmesi. (Yayımlanmamış Yüksek Lisans Tezi). İnönü Üniversitesi Eğitim Bilimleri Enstitüsü. Malatya

Demircan, N., \& Ceylan, A. (2003). Örgütsel güven kavramı: Nedenleri ve sonuçları. Yönetim ve Ekonomi: Celal Bayar Üniversitesi İktisadi ve İdari Bilimler Fakültesi Dergisi, 10 (2), 139-150. https://dergipark.org.tr/tr/pub/yonveek/issue/13679/165524

Ekin, S. (2019). Anadolu lisesi öğretmenlerinin örgütsel güven düzeyleri ile pozitif psikolojik sermaye düzeyleri. (Yayımlanmamış Yüksek Lisans Tezi). Dokuz Eylül Üniversitesi Eğitim Bilimleri Enstitüsü. İzmir

Erbaş, H. (2018). Öğretmenlerin pozitif psikolojik sermaye düzeyleri ile öğrenen özerkliğini destekleme davranışları. (Yayımlanmamış Yüksek Lisans Tezi). Abant İzzet Baysal Üniversitesi Eğitim Bilimleri Enstitüsü. Bolu

Erdem, H. (2014). Algılanan örgütsel destek ve kontrol odağının stresle başa çıkma yöntemleri üzerine etkileri: Psikolojik sermayenin bu süreçteki rolü ve bir alan araştırması. (Yayınlanmamış Doktora Tezi). İnönü Üniversitesi Sosyal Bilimler Enstitüsü. Malatya

Erdem, H., Gökmen, Y., ve Türen, U. (2015). Psikolojik sermayenin örgütsel özdeşleşme üzerine etkisinde algılanan örgütsel desteğin aracılık rolü. İşletme Araştırmaları Dergisi, 7(2), 38-62. 
Erenler Tekmen, E., Çetin, A., \& Torun, T. (2016). Çalışanların öz-yeterliklerine ilişkin algılarının sessizlik davranışları üzerine etkisi. Ekonomik ve Sosyal Araştırmalar Dergisi, 12, 71-99. https://dergipark.org.tr/en/pub/esad/issue/38968/456106

Erkuş, A., \& Fındıkl1, M. A. (2013). Psikolojik sermayenin iş tatmini, iş performansı ve işten ayrılma niyeti üzerindeki etkisine yönelik bir araştırma. Istanbul University Journal of the School of Business Administration, 42(2), 302-318.

Fettahlıoğlu, Ö.O., \& Koca, N. (2015). Örgütsel özdeşleşme ve örgütsel vatandaşlık ilişkisinde örgütsel desteğin düzenleyici etkisi. Sosyal Bilimler Dergisi, 2(4), 1-10.

Gay, L.R., \& Airasian P. (1999). Educational research: competencies for analysis and applications. (6. Edition). New Jersey: Merrill Publishing Company.

George, D., \& Mallery, P. (2010). SPSS for windows step by step: A simple guide and reference 17.0 update. (10th Edition). Boston: Pearson.

Halis, M. (2018). İnsan ilişkilerinin temeli güven ve güven yönetimi. http://www.gonuldergisi.com/insan-iliskilerinin-temeli-guven-guven-yonetimi-drminehalis.html adresinden 15.05.2020 tarihinde alınmıştır.

Hayes, C. T., \& Weathington, B. L. (2007). Optimism, stress, life satisfaction, and job burnout in restaurant managers. The Journal of Psychology, 141(6), 565-579.

Hırlak, B., Taşlıyan, M., \& Sezer, B. (2017). İyimserlik ve yaşam doyumu arasındaki ilişki ve demografik özellikler bağlamında algı farklılıkları: Bir alan araştırması. Kahramanmaraş Sütçü İmam Üniversitesi İktisadi ve İdari Bilimler Fakültesi Dergisi, 7 (1), 95-116.

İyem, C., \& Erol, E. (2013). Mesleki yönelimlerde bireylerin kişilik ve demografik özelliklerinin rolü: Sakarya Üniversitesi İşletme Bölümü Örneği. Sosyal ve Beşeri Bilimler Dergisi, 5 (1), 137-146.

Kartal, S. E. (2010). Genel liseler ile mesleki ve teknik liselerdeki öğretmenlerin örgütsel güven düzeylerinin karşılaştırılması (Elazığ ili örneği). (Yayımlanmamış Yüksek Lisans Tezi). Fırat Üniversitesi Sosyal Bilimler Enstitüsü. Elazı̆̆

Kavi, E., \& Karakale, B. (2018). Çalışan psikolojisi açısından psikolojik dayanıklılık. Hak $\dot{I}_{S ̧}$ Uluslararası Emek ve Toplum Dergisi, 7 (17), 55-77.

Kelekçi, H., \& Yılmaz, K. (2015). Öğretmenlerin pozitif psikolojik sermayeleri ile yeterlik inançları arasındaki ilişki. Mersin Üniversitesi Eğitim Fakültesi Dergisi, 11(3), 992-1007. DOI: 10.17860/efd.96988

Keleş, H. N. (2011). Pozitif psikolojik sermaye: tanımı, bileşenleri ve örgüt yönetimine etkileri. Organizasyon ve Yönetim Bilimleri Dergisi, 3(2), 343-350.

Kutanis, Ö.R., \& Oruç, E. (2014). Pozitif örgütsel davranış ve pozitif psikolojik sermaye üzerine kavramsal bir inceleme. The Journal Of Happiness \& Well-Being, 2(2), 145-159

Lu, L., Liu, L., Sui, G., \& Wang, L. (2015). The associations of job stress and organizational identification with job satisfaction among Chinese police officers: the mediating role of psychological capital. International Journal of Environmental Research and Public Health, 12(12), 15088-15099.

Luthans, F. (2002). Positive organizational behavior: Developing and managing psychological strengths. Academy of Management Perspectives, 16(1), 57-72.

Luthans, F., Avolio, B.J.; Avey, J.B., \& Norman, S.M. (2007a). Positive psychological capital: measurement and relationship with performance and satisfaction. Personnel Psychology, 60, 541-572.

Luthans, K. W., \& Jensen, S. M. (2005). The linkage between psychological capital and commitment to organizational mission: A study of nurses. JONA: The Journal of Nursing Administration, 35(6), 304-310. 
Luthans, F., Luthans, K. W., \& Luthans, B. C. (2004). Positive psychological capital: beyond human and social capital. Business Horizons, 47(1), 45-50. DOI: 10.1016/j.bushor.2003.11.007

Luthans, F., Norman, S.M., Avolio, B.J., \& Avey, J.B. (2008). The mediating role of psychological capital in the supportive organizational climate: Employee performance relationship. Journal of Organizational Behavior, 29 (2), 219-238.

Luthans, F., \& Youssef, C. M. (2004), Human, socialand now positive psychological capital management: Investing in people for competitive advantage. Organizational Dynamics, 33(2), 143-160.

Luthans, F., Youssef, C. M., \& Avolio, B. J. (2007b). Psychological capital. New York, NY: Oxford University Press.

Memduhoğlu, H. B., \& Zengin, M. (2011). İlköğretim okullarında örgütsel güvene ilişkin öğretmen görüşleri. Yüzüncü Yıl Üniversitesi Eğitim Fakültesi Dergisi, 8(1), 211- 217.

Ok, Ü. (2019). Pozitif psikoloji mi negatif psikoloji mi?. Açık Medeniyet Dergisi, 2(13), 4-7.

Outten, H. R., Schmitt, M. T., Garcia, D. M., \& Branscombe, N. R. (2009). Coping options: Missing links between minority group identification and psychological well-being. Applied Psychology: An International Review, 58(1), 146-170. DOI:10.1111/j.1464-0597.2008.00386.x

Öğüt, A., Akgemci, T., \& Demirsel, M. T. (2004). Stratejik insan kaynakları yönetimi bağlamında örgütlerde işgören motivasyonu süreci. Selçuk Üniversitesi Sosyal Bilimler Enstitüsü Dergisi, (12), 277-290.

Ötken, A., \& Erben, G. (2010). Örgütsel özdeşleşme ve işle bütünleşme arasındaki ilişkinin ve amir desteğinin rolünün incelenmesi. Gazi Üniversitesi İktisadi ve İdari Bilimler Fakültesi Dergisi, 12(2), 93-118.

Özerkan, E. (2007). Öğretmenlerin öz-yeterlik algıları ile öğrencilerin sosyal bilgiler benlik kavramları arasındaki ilişki. (Yayımlanmamış Yüksek Lisans Tezi). Trakya Üniversitesi Sosyal Bilimler Enstitüsü. Edirne

Sarıc1, D. (2015). Öğretmenlerin iş doyumu ile pozitif psikolojik sermaye düzeylerine yönelik görüşleri (İzmir-Foça İlçesi Örneği). (Yayımlanmamış Yüksek Lisans Tezi). Abant İzzet Baysal Üniversitesi Eğitim Bilimleri Enstitüsü. Bolu

Savi-Çakar, F., Karataş, Z., \& Çakır, M.A. (2014). Yetişkin yılmazlık ölçeği: Türk kültürüne uyarlanması. Mehmet Akif Ersoy Üniversitesi Eğitim Fakültesi Dergisi, (32), 22-39.

Seçilmiş, G. (2019). Pozitif psikolojik sermaye birey örgüt uyumu ve örgütsel yabancılaşma arasındaki ilişsi. (Yayımlanmamış Yüksek Lisans Tezi). Eskişehir Osmangazi Üniversitesi Eğitim Bilimleri Enstitüsü. Eskişehir

Sezgin, F. (2012). İlköğretim okulu öğretmenlerinin psikolojik dayanıklılık düzeylerinin incelenmesi. Kastamonu Ĕ̈itim Dergisi, 20(2), 489-502.

Şahin, E. (2014). Ortaöğretim kurumlarında örgütsel kimlik, örgütsel imaj, örgütsel özdeşleşme ve örgütsel adalet (Bursa örneği) (Yayımlanmamış Doktora Tezi). Ege Üniversitesi Sosyal Bilimler Enstitüsü. İzmir

Şimşek, H.A. (2018). Öğretmenlerin pozitif psikolojik sermaye düzeyleri ile okul müdürlerine yönelik öğretimsel liderlik algıları arasındaki ilişki (Çanakkale örneği). (Yayımlanmamış Yüksek Lisans Tezi). Çanakkale Onsekiz Mart Üniversitesi Eğitim Bilimleri Enstitüsü. Çanakkale

Tarhan, (2012). Güven. https://www.nevzattarhan.com/guven.html adresinden 15.05.2020 tarihinde alınmıştır.

Tarhan, N. (2019). 10 adımda pozitif psikoloji. (9. baskı). İstanbul: Timaş.

Tösten, R. (2015). Öğretmenlerin pozitif psikolojik sermayelerine ilişkin algılarının incelenmesi. (Yayımlanmamış Doktora Tezi). Gaziantep Üniversitesi Eğitim Bilimleri Enstitüsü. Gaziantep 
Tösten, R., \& Özgan, H. (2014). Pozitif psikolojik sermaye ölçeği: Geçerlik ve güvenirlik çalışması. EKEV Akademi Dergisi, 59(59), 429-442.

Tösten, R., \& Özgan, H. (2017) Öğretmenlerin pozitif psikolojik sermayelerine ilişkin algılarının incelenmesi. Elektronik Sosyal Bilimler Dergisi, 16 (62), 867-889

Turunç, Ö., \& Çelik, M. (2010). Algılanan örgütsel desteğin çalışanların iş-aile, aile-iş çatışması, örgütsel özdeşleşme ve işten ayrılma niyetine etkisi: Savunma sektöründe bir araştırma. Atatürk Üniversitesi Sosyal Bilimler Enstitüsü Dergisi, 14 (1), 209-232.

Türk Dil Kurumu. (2019). Büyük Türkçe Sözlük. Ankara: TDK.

Tüzün, D., \& Çağlar, D. (2008). Örgütsel özdeşleşme kavramı ve iletişim etkililiği ilişkisi. Journal of Yaşar University, 3 (9), 1011-1027.

Uysal, A., \& Gürol, M. (2018). Sosyal bilgiler öğretmenlerinin öğretime yönelik özgüven ölçeğinin geliştirilmesi. Uluslararası Alan Eğitimi Dergisi, 4(2), 1-12.

Üngören, E., \& Ercan, A. (2015). Sessizleşen örgütlerde öz yeterlilik algısının rolü: Alanya'daki konaklama işletmeleri üzerinde araştırma. İşletme Araşstırmaları Dergisi, 7 (2), 115-156.

Yazar, F., \& Özutku, H. (2019). Psikolojik sermayenin örgütsel bağlllık üzerindeki etkisine yönelik bir araştırma. Afyon Kocatepe Üniversitesi İktisadi ve İdari Bilimler Fakültesi Dergisi, 21 (2), 7081.

Yılmaz, F. (2020). Pozitif psikolojik sermayenin demografik değişkenler açısından değerlendirilmesi. International Journal of Management and Administration, 4(7), 71-83.

Yıldırım, İ. (2019). Öğretmenlerin pozitif psikolojik sermaye algıları ile mesleki adanmışlıklarının incelenmesi. (Yayımlanmamış Yüksek Lisans Tezi). Siirt Üniversitesi Sosyal Bilimler Enstitüsü. Siirt

Yücel, E. (2019). Pozitif psikolojik sermayenin iş tatminine etkisi: Turizm sektöründe bir araştırma. Business and Management Studies An International Journal, 7(4), 1136-1154. DOI: $10.15295 / \mathrm{bmij} . v 7 \mathrm{i} 4.1213$

\section{Extended Abstract}

\section{Introduction}

Due to the change and competition in every field in recent years, the importance given to human resources in organizations has increased even more. In organizations, there has been a tendency towards concepts such as positive psychology, positive organizational behavior, positive psychological capital in order to understand the value of humans and benefit from it better. Highlighting the positive aspects of employees and making researches on them, constitutes the basis of positive psychological capital. When employees encounter a positive atmosphere in their organizations, they may want to develop themselves more. This situation causes the employees to have positive thoughts about the organization. In such an environment, employees will feel that they belong to their organizations. Organizational identification, which is explained as employees' perceiving themselves as a part of their organization and establishing a psychological bond with their organization, is what organizations want. Studies have revealed that positive psychological capital and its components are related to issues such as performance, job satisfaction, employee happiness, organizational commitment and positively affect these concepts. The main purpose of this study is to determine whether there is a relationship between the positive psychological capital levels of teachers working in secondary schools and their organizational identification.

\section{Methodology}

In this study, the relational survey model was used. The sample of the study consists of 331 teachers working in the secondary schools in Antalya province Kepez District in the 2018-2019 academic year. Positive Psychological Capital Scale developed by Tösten and Özgan (2014) was used to determine teachers' perceptions of their positive psychological capital. The Organizational Identification Scale was 
used to determine teachers' perceptions of their organizational identification levels. This scale, developed by Mael and Ashforth (1992) and adapted into Turkish by Şahin (2014). Frequency, arithmetic mean, standard deviation, correlation and multiple regression analysis were used to analyze the data.

\section{Findings}

The average of the answers given by the teachers to the items in positive psychological capital and subdimensions was found to be at least 4.16 and at most 4.61. While the teachers answered "I Mostly Agree" to the optimism dimension, they answered "I totally agree" to the other five sub-dimensions. It was observed that the mean score of teachers regarding their perception of organizational identification was 3.44, and their level of participation was at the level of "I mostly agree". A moderate relationship was found between the general positive psychological capital and organizational identification perceptions of teachers in a positive direction $(\mathrm{r}=0.420, \mathrm{p}<0.01)$. The sub-dimensions of positive psychological capital explain $23 \%$ of the variance of organizational identification.

\section{Discussion}

When teachers 'perceptions of positive psychological capital, in general, are examined, it is seen that teachers' perceptions of positive psychological capital are very high. Luthans and Youssef (2004) state that psychological capital shapes employees' trust, hope, optimism and flexibility in their social life, and the organizations considering these psychological factors as a great alternative, has an important place in ensuring an effective work performance.

It can be seen that teachers' identification with their organizations is high. The success of organizations is possible not only with the competence and performance of their employees, but also by ensuring that the high-performance workforce remains loyal to the organization they work in (Ar1,2003).

Based on the result that teachers' positive psychological capital significantly affects their organizational identification, it can be said that teachers knowing that they are working in a school that values them by investments made in their positive psychological capital will make them feel more comfortable and peaceful. This may be an important factor in their adoption to the school.

*Bu makalede yazarların katkı oranları: Özlem YAZKAN \%70, Aydan ORDU \%30. 